\title{
Vitamin E Measurement
}

National Cancer Institute

\section{Source}

National Cancer Institute. Vitamin E Measurement. NCI Thesaurus. Code C74906.

The determination of the amount of Vitamin E present in a sample. 